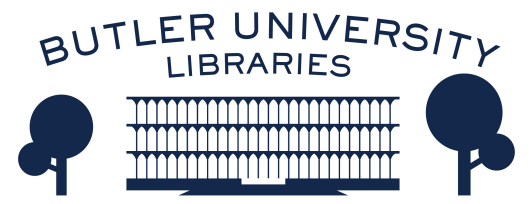

Journal of Hindu-Christian Studies

\title{
Book Review: "Ascent to the Depth of the Heart. The Spiritual Diary (1948-1973) of Swami Abhishiktananda (Dom H. Le Saux)."
}

Anand Amaladass

Follow this and additional works at: https://digitalcommons.butler.edu/jhcs

\section{Recommended Citation}

Amaladass, Anand (1999) "Book Review: "Ascent to the Depth of the Heart. The Spiritual Diary (1948-1973) of Swami Abhishiktananda (Dom H. Le Saux)."," Journal of Hindu-Christian Studies: Vol. 12, Article 18.

Available at: https://doi.org/10.7825/2164-6279.1216

The Journal of Hindu-Christian Studies is a publication of the Society for Hindu-Christian Studies. The digital version is made available by Digital Commons @ Butler University. For questions about the Journal or the Society, please contact cbauman@butler.edu. For more information about Digital Commons @ Butler University, please contact digitalscholarship@butler.edu. 
"history of the cross", Christians are able to know more truly. Vroom allows that Muhammad, though not a prophet in the full biblical sense, did have experience of God. Where it does not contradict the Bible, the Koran can thus be read "as the result of reflections on God's meeting with Muhammad" (124).

In his final chapter, Vroom asks bold and synthesizing questions. On the issue of whether Christians have access to knowledge about God not available to others, he restates his affirmative answer. However, this does not mean for him that Christians have the whole of knowledge and others have none. As to whether there is salvation beyond the Christian fold, he answers also in the affirmative: other traditions may provide access to salvation, or at least forms of salvation. Examining what they say about God (or the absolute), he concludes that, while the faithful of all the great traditions may experience transcendence of some kind, "not all religions worship the same God" (150). Buddhists and nondualist Hindus are distinctly disadvantaged in this respect. (Theistic Hindus receive more sympathy, but their case remains uncertain.) The author does allow that some who may thus be off the mark in their worship and meditation may still, no matter how mistakenly, intend the biblical God.

Vroom shows considerable respect and even at points admiration for his Buddhist, Hindu, and Muslim dialogue partners, but one is left with a sense that their voice has not really been attended to. Moreover, one senses an overconfidence, typical among Western philosophers, that enables Vroom to come to broad conclusions based entirely on the study of texts in translation and the application of logic. The author warns against over-determining God, but still wants to limit the divine and its expression through application of the law of noncontradiction. I would prefer a more careful method of prolonged dialogue with a single tradition, which would involve learning the languages, careful study of original texts, living among the believers, and so on. The results of such an approach - as seen, for example, in the work of Francis X. Clooney, SJ - are less sweeping. Indeed they are considerably more limited. Nevertheless, they are more authentic. Still, the questions raised by Vroom, though not really new, are important ones that have yet to be fully addressed. The critical edge maintains respect and provokes thought.

Lance E. Nelson University of San Diego

\section{Ascent to the Depth of the Heart. The Spiritual Diary (1948-1973) of Swami Abhishiktananda (Dom H. Le Saux). A Selection edited with introduction and notes by Raimon Panikkar. English Translation by David Fleming and James Stuart. ISPCK Delhi 1998. xxxvi +410 pp.}

HENRI LE SAUX (1910-1973), a French Benedictine monk, known as Swami Abhishiktananda, came to India in response to an inner call to a contemplative life, in tune with Indian tradition. His struggles and deep thoughts as recorded in his diary are placed before the readers through this publication. The title of this book is meant to suggest going beyond all the dualities, by using the paradox of the ascent to the depth (xii). Devoted friends of Abhishiktananda have taken meticulous care to translate the original text into English.

Abhishiktananda is already known to the public through his writings. But then $\mathrm{R}$. Panikkar in his perceptive introduction summing up the background of the author, points out the difference between the diary and the published writings:

In his books he is aware of his role as a 
Christian mystic who writes chiefly for Christians (and Westerners) in order to open their minds to Hindu wisdom. In his diary he is more and more the Hindu monk who is faced with the Christian mystery and is trying desperately to reconcile it with Vedanta. (xiv)

The author did not prepare the diary for publication. Personal details and jottings on various themes without further development do not normally go to press. We are told moreover that his disciple threw away certain portions of the diary, after copying what he considered to be relevant. However, the editorial committee seems to have reasons for publishing it. And Panikkar justifies it for three reasons: 1) it offers a fascinating example of the evolution of a thought process coming to the birth of a conviction out of his lived experience; 2) it shows us the transformation of a Christian grappling with himself, a testimony of a contemporary who, without breaking with his past, has been able to transform it, thanks to his faith and fidelity; 3 ) the value of the private diary lies in its revelation of the depths of a human being. His symbolizes a life lived in depth in the midst of a world that has fallen apart (xv-xvii).

The diary obviously reveals the man, since his books can speak for his ideas. The fact that he kept his diaries, noted his thoughts, the events that moved him, the inner struggle, amidst his travel, unfavourable circumstances as a wandering sannyasi, speaks of the man, his disciplined life, dedicated pursuit, still remaining warmhearted, being open to all in utter simplicity. $\mathrm{He}$ was thinking and searching and he has jotted down his insights that bear witness to a committed Christian who crossed the borders of his tradition to experience the other of the advaitic framework. Some felt that he had gone too far in taking the plunge into advaitic worldview. But he is a rare example of one who had the courage to enter into that kind of dialogue, which many Christians would not do. But that only adds to his greatness

The diary reveals the insights of Abhishiktananda, not as a theologian but as a mystic. Still, they have their theological significance. Some hesitate to take that seriously, since he was not a theologian and his diaries are not polished treatises on Christian faith. But one cannot but be struck by the way he has articulated his deeper experiences as a monk. In fact in the diary he is more transparent than in his books, since the author is in communion with his readers besides communicating his insights.

Abhishiktananda has affected many people. Though it is said that he did not have many disciples, his influence is felt much more through his writings. His vision of reality, which is dialogical, cross-cultural, authentically experience-centred as it is portrayed in his diaries, fascinatingly draws the attention of the reader to a new type of religious encounter for today.

This volume is a valuable contribution for those who are involved with the interreligious dialogue today. This work and the earlier publication, Swami Abhishiktananda, His Life Told through his Letters, (1989, 1995) by James Stuart, are companion volumes on the spiritual journey of a mystic who crossed the borders to find his own authentic self.

Anand Amaladass, SJ

Chennai, India

Encounters with Hinduism. Horst Georg Pöhlmann, transl. John Bowden. London: SCM Press, 1996, vii + 121 pp.

PÖHLMANN'S BOOK IS the outcome of his separate visits to South India in 1989 and 1993 to interview Hindus about their religious beliefs. The author undertook the interviews while staying as a visiting Professor at United Theological College in Bangalore. His research was funded by the Evangelical Lutheran Church of Germany 